\title{
MT-RNR2 Gene
}

National Cancer Institute

\section{Source}

National Cancer Institute. MT-RNR2 Gene. NCI Thesaurus. Code C131258.

This gene plays a role in both mitochondrial protein translation and apoptosis regulation. 